\title{
Extracellular heat shock proteins, cellular export vesicles, and the Stress Observation System: A form of communication during injury, infection, and cell damage
}

\author{
It is never known how far a controversial finding will go! \\ Dedicated to Ferruccio Ritossa
}

\author{
Antonio De Maio
}

Received: 4 October 2010 / Accepted: 6 October 2010 /Published online: 21 October 2010

(C) The Author(s) 2010. This article is published with open access at Springerlink.com

\begin{abstract}
Heat shock proteins (hsp) have been found to play a fundamental role in the recovery from multiple stress conditions and to offer protection from subsequent insults. The function of hsp during stress goes beyond their intracellular localization and chaperone role as they have been detected outside cells activating signaling pathways. Extracellular hsp are likely to act as indicators of the stress conditions, priming other cells, particularly of the immune system, to avoid the propagation of the insult. Some extracellular hsp, for instance Hsp70, are associated with export vesicles, displaying a robust activation of macrophages. We have coined the term Stress Observation System (SOS) for the mechanism for sensing extracellular hsp, which we propose is a form of cellular communication during stress conditions. An enigmatic and still poorly understood process is the mechanism for the release of hsp, which do not contain any consensus secretory signal. The export of hsp appears to be a very complex phenomenon encompassing different alternative pathways. Moreover, extracellular hsp may not come in a single flavor, but rather in a variety of physical conditions. This review addresses some of our current knowledge about the release and function of extracellular hsp, in particular those associated with vesicles.
\end{abstract}

Keywords Heat shock proteins · Stress · Exosomes · Microparticles · Cellular communication $\cdot$ Nonclassical secretory pathway $\cdot$ Inflammatory mediators

A. De Maio $(\triangle)$

School of Medicine, University of California San Diego,

9500 Gilman Drive, \#0739,

La Jolla, CA 92093-0739, USA

e-mail: ademaio@ucsd.edu

\section{Introduction}

Under normal physiological conditions, cells interact with each other to synchronize their metabolic activity, gene expression, and other basic cellular processes. In other words, cells communicate to maintain homeostasis. When cells are exposed to environmental changes, such as a variation in the availability of nutrients, they communicate to adjust their metabolism for the new condition. The same situation is true when cells are confronted by stressful circumstances. Thus, stressed cells release signals to alert the rest of the organism of a potentially damaging situation. We have coined the term Stress Observation System (SOS) for the mechanism responsible for the sensing of stress conditions in the extracellular environment. Some of the stress signals released by cells correspond to heat shock proteins (hsp), which are expressed in response to the insult. The mechanism involved in the release of hsp is still very mysterious, and their role in cell activation is only just beginning to be understood. This article presents a perspective on the release and role of extracellular hsp, in particular those hsp associated with membrane vesicles, in the activation of the immune system to combat injury and infection.

Expression of hsp: the universal response to stress

Almost 50 years ago, the Italian scientist Ferruccio Ritossa discovered the heat shock response by serendipity when one of his coworkers changed the temperature of his cell incubator. Ritossa observed a novel change in the pattern of Drosophila salivary gland puffs. As a good scientist, who kept impeccable records, he related the changes in the puffs with the higher temperatures, repeated the experiments with the appropriate controls, and the heat shock response was 
born. However, his discovery was initially rejected because, in the words of a prominent journal editor, "it was irrelevant to the scientific community" (Ritossa 1996), a story too often repeated with many other novel observations that challenge the conventional wisdom. Later, the stress response was correlated with the expression of hsp. A large number of hsp have been identified so far, and they are classified according to their molecular weight into discrete families. As is the case in many other disciplines, several names have been given to the same hsp. A consensus nomenclature has recently been proposed to avoid this problem (Kampinga et al. 2009). Some hsp are present in normal nonstress conditions, playing important roles in different intracellular processes, among which their role as molecular chaperones is the most recognized. In addition, their expression is enhanced or induced after a variety of stresses, including environmental and pathological conditions. The presence of hsp is important for the recovery from stress and protection from subsequent insults (De Maio 1999; Giffard et al. 2008). The biology of intracellular hsp during normal and stress conditions has been summarized by a large number of reviews (Lindquist and Craig 1988; Morimoto 1991; Bukau et al. 2006; Hartl and Hayer-Hartl 2009). Consequently, this aspect will not be further discussed in this article.

A new twist in the stress field is the detection of hsp outside cells. Initially, a heat-shock-like protein was described as a glia-axon transfer protein of the squid giant axon (Tytell et al. 1986). Independently, Hightower and Guidon (1989) found that Hsp70 was released from cells by a mechanism that cannot be blocked by inhibitors of classical secretory pathways. This observation, like Ritossa's discovery, was initially deemed irrelevant and impossible, in spite of a large number of appropriate controls. Thus, these early observations regarding the presence of hsp in the extracellular environment were disregarded for many years. It was not until another controversial finding was reported by Asea and Calderwood (Asea et al. 2000), who found that recombinant Hsp70 was capable of activating cells of the immune system, that a possible role for extracellular hsp was reborn. The results from Asea and Calderwood were disputed based on the possibility that the activation of immune cells was due to contamination by bacterial endotoxin (Gao and Tsan 2003; Bausinger et al. 2002), or other agents (Bendz et al. 2008). These worries have been ruled out by the use of recombinant Hsp70 isolated from insect cells, nonrecombinant Hsp70, treatment with polymyxin $\mathrm{B}$, boiling, or incubation in serumfree medium (Srivastava 1997; Vega et al. 2008; Zheng et al. 2010). Today, it is well established that Hsp70 is, indeed, responsible for the activation of macrophages, monocytes, dendritic cells (DC), natural killer (NK) cells, and hepatocytes, independently of contaminants (Asea et al. 2000; 2002; Basu et al. 2001; Vabulas et al. 2002; Gastpar et al.
2004; Wang et al. 2006; Kovalchin et al. 2006; Aneja et al. 2006; Vega et al. 2008; Galloway et al. 2008). Moreover, extracellular hsp have been shown to act as potent immunostimulatory or immunosuppressive molecules depending on the circumstances by which they interact with cells (Pockley et al. 2008).

Another controversial finding was related to the origin of extracellular hsp. Although Hightower and Guidon (1989) demonstrated that the release of Hsp70 was from healthy cells, others proposed that the major source of extracellular Hsp70 was due to cell lysis after necrosis (Basu et al. 2000). Hunter-Lavin et al. (2004) reported that Hsp70 was released by an active mechanism independent of cell death, confirming Hightower and Guidon's (1989) observations. However, these studies did not rule out the possibility that necrosis could be an additional source of extracellular Hsp70. In fact, we have observed that following regional hepatic ischemia/reperfusion injury in the rat, the majority of Hsp70 in circulation is due to liver necrosis (Vazquez and De Maio, unpublished observations). Consequently, there are two different sources of extracellular Hsp70: active, due to a nonconventional secretory process, and passive, secondary to cell death and lysis. In addition to Hsp70, other hsp have been detected outside cells, such as Hsp60 (Merendino et al. 2010), Hsp90 (Tsutsumi and Neckers 2007; Sidera and Patsavoudi 2008), Grp78 (Delpino and Castelli 2002; Kern et al. 2009), and Hsp27 (Liao et al. 2009). The importance of extracellular hsp has been enlightened by the detection of Hsp70 in the serum of patients suffering from an array of conditions (Table 1). In addition, hsp have been found in the serum of apparently healthy individuals (Pockley et al. 1998). The presence of Hsp70 in circulation has also been correlated with improved survival of critically ill patients (Pittet et al. 2002; Ziegler et al. 2005). Other extracellular hsp, including Hsp27 (Liao et al. 2009), Hsp60 (Zhang et al. 2008), and Hsp90 (Tsutsumi and Neckers 2007) have been additionally linked to several diseases.

\section{Mechanisms for the export of hsp}

The fact that hsp can be detected outside cells has been puzzling, since the majority of these proteins lack the consensus signal required for secretion via the classical endoplasmic reticulum (ER)-Golgi pathway. With the exception of ER-resident hsp (Grp78 and Grp94), the majority of hsp are synthesized in the cytosol and exported to the extracellular space by an active mechanism that cannot be blocked by typical inhibitors of the ER-Golgi pathway, such as brefaldin A. Consequently, they are likely to be released by an alternative mechanism, coined the nonclassical secretory or unconventional pathway (reviewed by Nickel and Seedorf 2008). It appears that 
Table 1 Extracellular Hsp70 in disease

\begin{tabular}{ll}
\hline Disease & Reference \\
\hline Acute lung injury & Ganter et al. 2006 \\
Cancer & Azuma et al. 2003; Faure et al. 2004 \\
Chronic inflammation during aging & Njemini et al. 2004 \\
Coronary artery disease & Zhu et al. 2003; Genth-Zotz et al. 2004; Zhang et al. 2010a \\
Diabetes & Oglesbee et al. 2005 \\
Hypertension/pregnancy & Molvarec et al. 2006 \\
Infection & Njemini et al. 2003 \\
Ischemia/reperfusion & Hecker and McGarvey 2010 \\
Myocardial infarction & Dybdahl et al. 2005 \\
Trauma & Pittet et al. 2002; Ziegler et al. 2005 \\
\hline
\end{tabular}

the nonclassical secretory pathway is not a unique mechanism, but rather a collection of alternative passageways, which have as a common denominator the exclusion from the ER/Golgi compartment. The most prominent molecules secreted by the unconventional pathway are interleukin (IL) $-1 \alpha$ and $-1 \beta$, which are apparently released by several possible mechanisms (Eder 2008). Similarly to IL-1, the release of Hsp70 outside cells has been reported via different mechanisms. A lysosome-endosome pathway has been proposed (Mambula and Calderwood 2006). In this process, Hsp70 is translocated into lysomes, where the protein is spared from degradation and transported to the exterior of the cell via the endocytic process. Indeed, the presence of Hsp70 in the lumen of lysomes has been reported previously (Nylandsted et al. 2004). The translocation of Hsp70 into lysosomes has been proposed via an ATPbinding cassette $(\mathrm{ABC})$ transport-like system (Mambula and Calderwood 2006). Hsp70 has also been proposed to be released by secretory-like granules (Evdonin et al. 2006). We have argued that there is another mechanism for the export of Hsp70, which is mediated by the insertion of the protein into the membrane of export vesicles (Vega et al. 2008).

Another surprising and controversial finding has been the interaction of Hsp 70 with membranes. Initially, Alder et al. (1990) detected currents after the addition of Hsp70 to unilamellar lipid vesicles. Ten years later, we showed that Hsc70 was capable of integrating into an artificial lipid bilayer, opening cationic conductance channels, which were very stable and regulated by adenosine triphosphate/ diphosphate (ATP/ADP) (Arispe and De Maio 2000). Similarly, Hsp70 was also found to open ion conductance pathways in artificial lipid bilayers (Vega et al. 2008). These observations have been expanded by other studies in which both Hsc70 and Hsp70 were capable of inducing liposome aggregation in a time-, concentration-, and nucleotide-dependent manner (Arispe et al. 2002). Moreover, it was found that the specificity of Hsp70 and Hsc70 for lipids was highly related to the presence of phosphati- dylserine (PS) within membranes (Arispe et al. 2004; Schilling et al. 2009). New observations also revealed that Hsp70-induced PS-liposome aggregation could be enhanced by the coaddition of monosialotetrahexosylganglioside (GM1) and cholesterol (Fig. 1). Other sphingolipids, such as globotriaosylceramide, have also been reported to enhance Hsp70 insertion into membranes (Gehrmann et al. 2008; Sugawara et al. 2009). Recently, the specificity of Hsp70 for other lipids, such as anionic phospholipid bis(monoacylglycero)phosphate, has been reported (Nylandsted et al. 2004). In contrast, liposomes made of phosphatidylcholine, phosphatidylethanolamine, or phosphatidylinositol could not sustain Hsp70 membrane insertion and liposome aggregation, confirming that the presence of PS is fundamental for Hsp70 insertion (Arispe et al. 2004). Although both Hsc70 and Hsp70 channels showed the same specificity, their conductance was not identical (Arispe and De Maio 2000; Vega et al. 2008). Likewise, the kinetics of Hsc70- or Hsp70-induced liposome aggregation were different (Arispe et al. 2002), suggesting that these two protein are, indeed, functionally different, at least in their interaction with membranes. The stability observed in Hsp70/Hsc70 channels is remarkable for a protein that does not contain any consensus hydrophobic domain that can explain membrane insertion. In other words, the incorporation of Hsp70/Hsc70 into membranes cannot be predicted on the basis of their amino acid sequences. The mechanism for the insertion of Hsp70 within the lipid membrane is not known, but it is likely dependent on membrane fluidity (Horvath et al. 2008). We have proposed that Hsp70 membrane insertion may be related to the flipping/flopping of PS across the lipid bilayer. It is also possible that Hsp70/ Hsc70 oligomerizes prior to or during membrane insertion, which is likely necessary for ion channel formation. Hsc70 has been shown to form low-order oligomers (Schlossman et al. 1984; Gao et al. 1996; Fouchaq et al. 1999). The C terminus end of Hsp70/Hsc70 displays a $\beta$-sheet structure, which may act as an oligomerization center. Indeed, other 


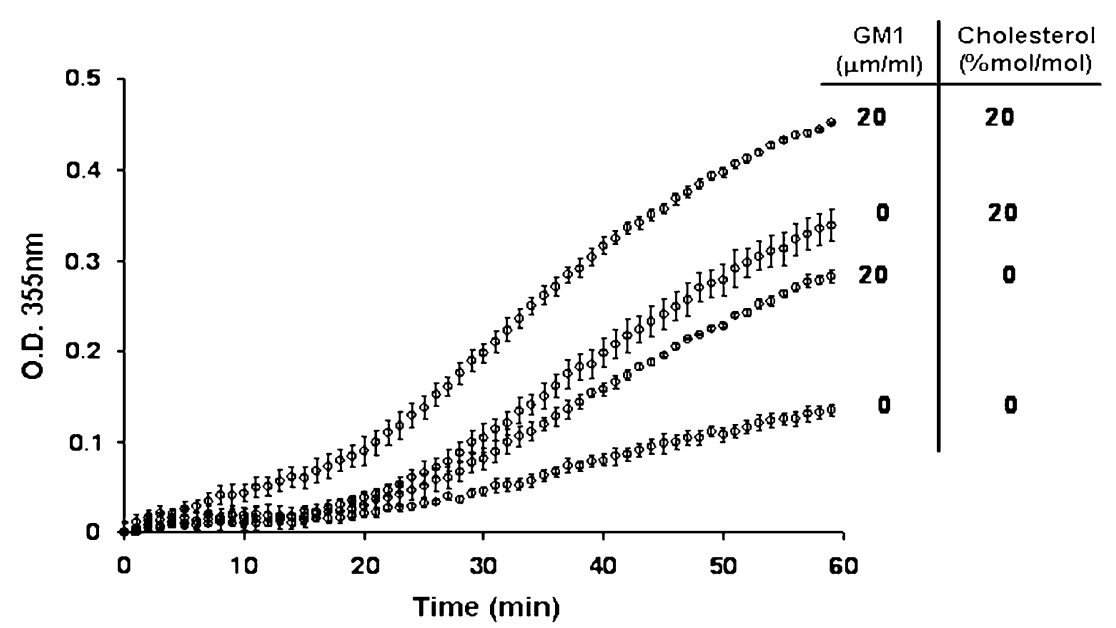

Fig. 1 Liposome aggregation induced by Hsp70, effect of cholesterol and GM1. The aggregation assay was performed with PS liposomes prepared with or without GM1 $(20 \mu \mathrm{g} / \mathrm{ml})$, cholesterol $(20 \% \mathrm{~mol} / \mathrm{mol})$ or a combination of both. Liposomes were incubated with Hsp70
$(10 \mu \mathrm{g} / \mathrm{ml})$ in $40 \mathrm{mM}$ histidine- $\mathrm{HCl}, \mathrm{pH} 6,300 \mathrm{mM}$ sucrose, $0.5 \mathrm{mM}$ $\mathrm{MgCl}_{2}, 1 \mathrm{mM} \mathrm{CaCl}_{2}$ at $25^{\circ} \mathrm{C}$, and the change in absorbance produced as a result of the aggregation process was measured at $350 \mathrm{~nm}$ in a Hewlett Packard spectrophotometer, with data collected every $30 \mathrm{~s}$ proteins with similar $\beta$-sheet structures, such as annexin, amyloid, and amylin, have been shown to form ion channels in artificial lipid bilayers (Rojas et al. 1992; Arispe et al. 1993, 1996).

The discovery of Hsp70 insertion into membranes provided an explanation for another divisive topic, the presence of hsp on the cell surface. Initially, Ferrarini et al. (1992) detected Hsp90 and, to a lesser extent, Hsp70 on the surface of several tumor cell lines. This observation was followed by a more extensive characterization of Hsp70 on the surface of transformed cells by Multhoff et al. (1995). These discoveries remained controversial for many years despite a large number of publications confirming this phenomenon (reviewed by Multhoff and Hightower 1996; Multhoff 2007). Several lines of evidence suggested that Hsp70 was not simply associated to a membrane protein, but rather inserted into the plasma membrane. The strongest argument for this observation was that only an antibody that recognized a small epitope on the $\mathrm{C}$ terminus end of the molecule was capable of detecting Hsp70 on the cell surface (Botzler et al. 1998). In addition, Hsp70 within the plasma membrane was found resistant to acid or basic washes (Vega et al. 2008; Gehrmann et al. 2008). Interestingly, the protein within the cell surface was found resistant to solubilization by nonionic detergents (Vega et al. 2008), suggesting that the protein may be localized within detergent-resistant microdomains (DRM), or lipid rafts, which are rich in cholesterol and sphingolipids (Brown and London 2000). Indeed, Hsp70 has been detected within the DRM fraction isolated from cells (Triantafilou et al. 2002; Broquet et al. 2003; Hunter-Lavin et al. 2004; Chen et al. 2005; Wang et al. 2006; Vega et al. 2008). These observations are supported by our findings demonstrating an increase in aggregation by addition of cholesterol and/or GM1 to PS liposomes (Fig. 1). The presence of Hsp70 and other hsp on the cell surface has been widely reported by many investigators under different physiological or pathological conditions (Table 2). Moreover, the observation that Hsp70 can be inserted into the plasma membrane opens the possibility that this association may be the gateway for the release of the protein to the extracellular space. In fact, Hsp70-containing vesicles, which were derived from the plasma membrane, have been detected in the extracellular medium (Gastpar et al. 2005; Vega et al. 2008; Chalmin et al. 2010). Hsp70 was found on the surface of these vesicles, presenting many of the characteristics of the protein within the plasma membrane, such as insolubility by Triton X-100 (Vega et al. 2008).

Another alternative mechanism for the export of hsp proteins may be related to the release of cargo within extracellular vesicles. Indeed, several hsp have been detected within extracellular vesicles (Table 3 ). It is very likely that cytosolic proteins, including hsp, are trapped or actively transported into the lumen of extracellular vesicles and are consequently released into the outer cellular space. Alterations in the vesicle integrity may result in the release of the cargo into circulation. A potential example for this mechanism is related to the release of high-mobility group box 1 (HMGB-1), which is not secreted by the ER-Golgi pathway (Gardella et al. 2002). HMGB-1 has been reported in extracellular vesicles derived from stimulated human epithelial cells (Liu et al. 2006). Thus, it is possible that HMBG-1 is packed into extracellular vesicles that are released into circulation, which eventually release their cargo, including this important inflammatory agent (Yang et al. 2005). This possibility matches the initial observation about the detection 
Table 2 Detection of hsp on the cell surface

\begin{tabular}{|c|c|c|c|c|}
\hline Hsp & Suggested name & Cells & Remarks & References \\
\hline \multirow[t]{14}{*}{ Hsp70 } & \multirow[t]{14}{*}{ HSPA } & $\begin{array}{l}\text { Human Ewing's sarcoma and } \\
\text { osteosarcoma cells }\end{array}$ & \multirow[t]{7}{*}{ HS/recovery } & Multhoff et al. 1995 \\
\hline & & $\begin{array}{l}\text { Human lung (LX-1) and mammary } \\
(\mathrm{MX}-1) \text { carcinoma cells }\end{array}$ & & Botzler et al. 1998 \\
\hline & & $\begin{array}{l}\text { Human oral dysplasia and squamous } \\
\text { cell carcinoma }\end{array}$ & & Kaur et al. 1998 \\
\hline & & Tumor biopsies & & Hantschel et al. 2000 \\
\hline & & Melanoma biopsies & & Farkas et al. 2003 \\
\hline & & Acute myeloid leukemia cells & & Gehrmann et al. 2003 \\
\hline & & Head-and-neck tumors & & Kleinjung et al. 2003 \\
\hline & & Human neutrophils & \multirow[t]{2}{*}{ LPS } & Hirsh et al. 2006 \\
\hline & & $\begin{array}{l}\text { Human colon }(\mathrm{CX} 2) \text { and pancreas } \\
(\text { Colo357) carcinoma cells }\end{array}$ & & Gehrmann et al. 2008 \\
\hline & & Human HepG2 cells & \multirow[t]{2}{*}{ HS/recovery } & Vega et al. 2008 \\
\hline & & Human fibroblast-like synovial cells & & Sedlackova et al. 2009 \\
\hline & & Colon carcinoma cells (CX2) & \multirow[t]{2}{*}{ Hypoxia } & Schilling et al. 2009 \\
\hline & & Murine LL/2 lung carcinoma & & Tani et al. 2009 \\
\hline & & Human Leukemia cells (U-937) & Heat shock & Lasunskaia et al. 2010 \\
\hline Hsp70B & HSPA6 & Human colon cells (HT-29, CRL-1809) & Proteosome inhibitors & Noonan et al. 2008 \\
\hline Hsp70/Hsp25 & HSPA/HSPB1 & $\begin{array}{l}\text { Human mammary adenocarcinoma } \\
\text { cells (4T1) }\end{array}$ & \multirow[t]{4}{*}{ Normal/heat shock } & Bausero et al. 2004 \\
\hline Hsp70/Hsp90 & HSPA/HSPC & $\begin{array}{l}\text { Human tumor cell lines GLCl } \\
\text { (microcitoma), lung carcinoma } \\
\text { (P71 and A549), melanoma } \\
\text { (MEL10 and M14), hepatoma (HEPAl) }\end{array}$ & & Ferrarini et al. 1992 \\
\hline Hsp90 & HSPC & Human neuroblastoma (NB69) cells & & $\begin{array}{l}\text { Cid et al. 2009; Tsutsumi } \\
\text { and Neckers } 2007\end{array}$ \\
\hline Hsp90ß & HSPC3 & $\begin{array}{l}\text { Multipotential mesenchymal } \\
\text { precursor cells }\end{array}$ & & Gronthos et al. 1999 \\
\hline \multirow[t]{2}{*}{ Grp94 } & \multirow[t]{2}{*}{ HSPC4 } & Meth A sarcoma & \multirow[t]{2}{*}{$\begin{array}{l}\text { Enhanced HS } \\
\text { and exposure } \\
\text { to reducing agents }\end{array}$} & Altmeyer et al. 1996. \\
\hline & & Xenopus lymphoid tumor cell lines & & Robert et al. 1999 \\
\hline Hsp60 & HSPD1 & Liver/spleen & Infection & Belles et al. 1999 \\
\hline \multirow[t]{4}{*}{ Grp78 } & \multirow[t]{4}{*}{ HSPA5 } & Rat exocrine pancreas & & Takemoto et al. 1992 \\
\hline & & $\begin{array}{l}\text { Atherosclerotic lesion } \\
\text { (293T endothelial cells) }\end{array}$ & ER stress & Zhang et al. $2010 \mathrm{~b}$ \\
\hline & & & overexpression & Liu et al. 2003 \\
\hline & & Prostate cancer cells (DU 145) & & Arap et al. 2004 \\
\hline Hsp90/Hsp70/Hsp27 & HSPC/HSPA/HSB1 & Dog neutrophils & $\mathrm{H} 2 \mathrm{O} 2$ & Camins et al. 1999 \\
\hline Hsc70 & HSPA8 & $\begin{array}{l}\text { Bile duct formation in newborn } \\
\text { rat liver }\end{array}$ & Morphogenic maturation & Mills et al. 2010 \\
\hline
\end{tabular}

of HMBG-1 in circulation during late sepsis (Wang et al. 1999). Similarly, exocytosis of endolysosome-related vesicles has also been proposed for the release of IL-1 $\beta$ (Andrei et al. 1999; MacKenzie et al. 2001).

Cell communication via extracellular vesicles

There are several ways that cells can communicate with each other. The most common is via soluble molecules that are placed in the extracellular environment and interact with adjacent or distant cells via specific receptors. The typical examples of this type of communication are hormones and cytokines. Cells that are placed together can also communicate via surface contact molecules, such as adhesion proteins, which have been coined "cellular synapses" (Ahmed and Xiang 2010). Moreover, cells in close proximity can exchange surface molecules by the direct transfer of membrane portions, which is known as trogocytosis, or by 
Table 3 Hsp detected within extracellular vesicles

\begin{tabular}{lll}
\hline Hsp & Cells & Reference \\
\hline Hsc70/Hsp70 & Reticulocytes & Mathew et al. 1995 \\
Hsp90, Hsc70 & Mesothelioma & Hegmans et al. 2004 \\
Hsp70 & PBMC & Lancaster and Febbraio 2005 \\
Hsp70, Hsc70, hsp 27, Hsp 90 & B cells & Clayton et al. 2005 \\
Hsp70 & DC & Thery et al. 1999 \\
Hsp70 & Colo357/CX2 & Gastpar et al. 2005 \\
Hsp70, Hsp90, grp78 & Rat hepatocytes & Conde-Vancells et al. 2008 \\
Hsp90 & Dendritic cells (DC) & Chaput et al. 2006 \\
Mortalin/Grp75 & K562 & Pilzer and Fishelson 2005 \\
Hsp70 & HepG2 & Vega et al. 2008 \\
Hsp70 & EL4 thymoma, TS/A mammary carcinoma, and CT26 colon carcinoma & Chalmin et al. 2010 \\
Hsp70 & mycobacteria-infected (M. smegmatis and M. avium) RAW 264.7 & Anand et al. 1999 \\
Hsp90 & A172, HT-1080, MDA-MB231 & McCready et al. 2010 \\
\hline
\end{tabular}

membrane tethers or nanotubes (Davis 2007). In addition, adjacent cells can exchange low-molecular-weight metabolites by passing them from cell to cell via gap junctions (De Maio et al. 2002). An alternative mechanism for cellular communication could be mediated by membrane vesicles released by one cell and captured by another. These vesicles contain surface molecules, lipids, and cargo, which can be of different natures, including proteins, nucleic acids, carbohydrates, and small molecules.

The importance of cellular communication via vesicles is that they contain a large number of molecules in a small volume. Thus, every target cell can be hit at the same time by a great number of recognition or signaling molecules, which is likely to be more effective than the activity of individual components in solution. For example, activation of macrophages by Hsp70 is increasingly elevated when the protein is associated with vesicles, more than 250-fold higher than the same concentration of the hsp in solution (Vega et al. 2008). This robust effect is likely due to the high concentration of Hsp70 within the vesicle. In fact, the concentration of a ligand within a $100-\mathrm{nm}$ vesicle is theoretically calculated in the millimolar range, which is much larger than the circulating concentration of any hormone or other cellular activator agent. Moreover, the multiplicity of different molecules per vesicle adds a synergistic effect for the information transmitted to the target cell. In other words, different components of the vesicle could simultaneously activate various cellular pathways. The second advantage of communication via vesicles is that they can travel long distances before breaking down and releasing their cargo, which, indeed, protects the lumen components from factors that may affect their stability. The final stage for this mechanism of communication requires that extracellular vesicles are specifically recognized by target cells. Thus, it could be postulated that these vesicles interact with specific cells via surface molecules or receptors. In other words, surface molecules on the vesicles could act as recognition signals (zip codes) that direct the vesicles to specific receptors on cellular targets. These surface molecules could be directly involved in the activation of cells, or this role could be mediated by other components within the vesicles, such as cargo molecules. The process of vesicle interaction with the target cells may require endocytosis or membrane fusion.

\section{Extracellular vesicles have different origins}

The presence of extracellular vesicles has been known for a long time. However, the terminology, as in any emerging field, has been confusing, hindering the understanding of the role and origin of these vesicles. Extracellular vesicles have been coined exosomes, ectosomes, and microparticles, among many other names. Exosomes are small export vesicles initially derived from the plasma membrane, but by a mechanism involving endocytosis (Thery et al. 2009). In contrast, microparticles and ectosomes are derived directly from the plasma membrane by the formation of membrane protuberances. Initially, microparticles were described as the "dust" released by platelets (Wolf 1967). Since it was not initially clear whether or not they contained a membrane component, microparticles was an appropriate term. Today, it is known that they are encapsulated by a membrane, derived from the plasma membrane, and they may be very large, reaching diameters of up to $1,000 \mathrm{~nm}$ (Hugel et al. 2005; Meziani et al. 2008). Consequently, they are not properly microparticles, but rather macrovesicles. In contrast, ectosomes, which are derived from the plasma membrane, are smaller, about $50-100 \mathrm{~nm}$ in diameter 
(Thery et al. 2009). The composition of exosomes, ectosomes, and microparticles is likely to be different. Density in sucrose gradients has been used as a criterion to differentiate them. However, it is unclear whether exosomes and ectosomes indeed have different density. Since the common approach to isolate extracellular vesicles is by differential centrifugation, it has been very difficult to physically separate the various types of vesicles, making it complicated to determine their specific components or markers.

Exosomes were first described as being derived during the differentiation of reticulocytes as part of a mechanism to release unwanted molecules (Harding et al. 1983; Pan et al. 1985). They are derived by a process in which the plasma membrane is internalized by endocytosis, followed by the formation of late endosomes. In this last compartment, the membrane of the endocytic vesicle is invaginated inward and sealed, resulting in vesicles within larger vesicles, called multivesicular bodies (MVB). Then, MVB fuse with the plasma membrane, liberating the internal vesicles (exosomes), 40-100 nm, which are then free in the extracellular environment (Johnstone 2006; Thery et al. 2009). The major characteristic of this process is that the vesicles that are released have the same topology as the plasma membrane. However, not all plasma membrane components are present in exosomes, suggesting a level of specificity for their assembly. Exosomes have been found to contain transferrin receptor, tetraspanins (CD9, CD63, CD81, and CD82), and Glycosylphosphatidylinositol (GPI) anchored glycoproteins, such as acethylcholinesterase. In addition, exosomes are also rich in cholesterol and sphingolipids (Simpson et al. 2008; Thery et al. 2009). These observations suggest that DRM or lipid rafts are present in these extracellular vesicles (de Gassart et al. 2003). Exosomes also contain some members of the endocytosis pathway, such as Rabs, which have been implicated in exosome formation (Savina et al. 2002; Ostrowski et al. 2010). Moreover, the release of exosomes is apparently calcium-dependent (Savina et al. 2003). Since exosomes are made by invaginations of the endosomal membrane, they pinch out some cytosolic molecules. In fact, a protein that has been detected in many exosome preparations is Hsc70. Originally, it was speculated that Hsc70 was present because of its high cytosolic abundance (approximately $10^{7}$ molecules/cell). However, other proteins present in large concentrations in the cytosol have not been detected in exosomes. Thus, the theory is that the composition of exosome cargo is also very specific. Exosomes have been observed derived from a large number of cells in different physiological conditions (Simpson et al. 2008), including B cells (Raposo et al. 1996), T cells (Blanchard et al. 2002), DC (Zitvogel et al. 1998), macrophages (Bhatnagar et al. 2007), and mast cells (Raposo et al.
1997). They have been also associated with an important role in cancer and pathogen biology (Schorey and Bhatnagar 2008; O’Neill and Quah 2008).

In contrast to exosomes, microparticles, or ectosomes, are derived directly from the plasma membrane without the involvement of the endocytic pathway. The mechanism implies the formation of membrane protuberances or blebs, which at critical sizes are sealed and released (Hugel et al. 2005; Meziani et al. 2008). These vesicles are also likely to contain plasma membrane components and several cytosolic factors that are imported into the emerging vesicle. Interestingly, ectosomes and microparticles are also very rich in lipid raft components (Hugel et al. 2005; Lopez et al. 2005). In fact, it has been proposed that microparticles are derived from lipid rafts (del Conde et al. 2005). Similarly with exosomes, microparticles, or ectosomes, are not absolute replicas of the plasma membrane, suggesting a level of selectivity in their formation. These vesicles also likely require actin polymerization for their formation. Consequently, it is possible that $\mathrm{F}$-actin is present within them. As mentioned above, microparticles tend to be large $(100-1000 \mathrm{~nm})$ and can be isolated by low $g$ force and characterized by flow cytometry (Thery et al. 2009; Gelderman and Simak 2008). Microparticles have been shown to display immunosuppressive function (Sadallah et al. 2008), and they have also been implicated in angiogenesis (Mostefai et al. 2008). Microparticles have been proposed as markers of endothelium dysfunction (Horstman et al. 2004) and other conditions (Smalley and Ley 2008; Meziani et al. 2008). Small vesicles, which are commonly called ectosomes, might also be released through budding of the plasma membrane. Thus, size is not the main criteria to classify extracellular vesicles as exosomes or ectosomes. Therefore, the term exosomes should be restricted to vesicles that are derived via MVB. In other words, not all 5- to $100-\mathrm{nm}$ vesicles detected outside cells are exosomes. Microparticles, ectosomes, and exosomes are different than vesicles derived from apoptotic cells. During cell death, there is a significant bleed of the plasma membrane and a release of vesicles, which have been coined apoptotic blebs or apoptotic vesicles. These vesicles are likely part of the cell shrinking process during apoptosis (Hristov et al. 2004). Apoptotic blebs probably contain a large variety of cellular components (membrane, cytosolic, and nuclear) without any specificity. They are possibly of different sizes and denser than exosomes (Thery et al. 2009). Their biological role, if any, remains to be established.

Extracellular vesicles and the SOS

Cells also secrete extracellular or export vesicles in response to stress, which could be specifically coined 
Stress Cellular Vesicles. The idea is that these extracellular vesicles contain particular molecules, such as hsp, whose expression is induced during the stress. These extracellular vesicles are recognized by other cell types, in particular cells of the immune system, as part of an assessment of the stress conditions. Particular components of extracellular vesicles may act as signals to activate a preemptive response in distant cells. We have coined this phenomenon the SOS. It is likely that the specific cellular response depends on the composition of extracellular vesicles. The presence of extracellular vesicles has been observed in a large number of disease conditions (Table 4). For example, extracellular vesicles that were isolated from the plasma of septic patients induced myocardial dysfunction in isolated rabbit hearts and rat papillary muscle preparations (Azevedo et al. 2007). The incidence of aortic valve stenosis has been associated with the presence of extracellular vesicles derived from platelets after high shear stress. These extracellular vesicles could further activate leukocytes and monocytes to produce more vesicles, resulting in endothelial cell injury (Diehl et al. 2008; Ahn et al. 2008). Extracellular vesicles derived from macrophages infected with intracellular pathogens were found to activate uninfected macrophages by a Toll-like receptor (Tlr) and myeloid differentiation factor 88 (My88) mechanism. They also induced polymorphonuclear leukocyte recruitment in lungs after intranasal delivery (Bhatnagar et al. 2007). Export vesicles isolated in the bronchoalveolar fluid of allergen-tolerized mice were reported to prevent an allergic reaction (Prado et al. 2008). Extracellular vesicles have been purified from different sources, including epididymal fluid and seminal plasma (Gatti et al. 2005), broncoalveolar fluid (Admyre et al. 2003), amniotic fluid (Keller et al. 2007), blood (Caby et al. 2005), and urine (Keller et al. 2007).

Hsp have been detected in preparations of extracellular vesicles from different cell types as mentioned before (Table 3). Moreover, these hsp-containing vesicles have been found to have a biological function. For example, vesicles containing Hsp70 on their surface displayed a robust and specific activation of macrophages, which was more robust than the same concentration of recombinant Hsp70 in solution (Vega et al. 2008). Hsp70-positive extracellular

Table 4 Extracellular vesicles in disease

\begin{tabular}{|c|c|c|}
\hline Disease & Source of ECV & References (101-125) \\
\hline Acute Coronary Syndromes & Endothelial cells, platelets & Mallat et al. 2000; Bernal-Mizrachi et al. 2004 \\
\hline Acute ischemic stroke & Endothelial cells & Simak et al. 2006 \\
\hline Allergy & Bronchial alveolar fluids & Prado et al. 2008 \\
\hline Aortic valve stenosis & Platelets & Diehl et al. 2008 \\
\hline Arteriosclerosis obliterans & Platelets & Nomura et al. 2000 \\
\hline Cancer & Several tumors or cell lines & $\begin{array}{l}\text { Hegmans et al. 2004; Gastpar et al. 2005; } \\
\text { Chalmin et al. } 2010\end{array}$ \\
\hline Cardiopulmonary bypass & Multiple sources & Nieuwland et al. 1997 \\
\hline Congestive heart failure & Endothelial cells & Rossig et al. 2000 \\
\hline Diabetes & Total, platelets, monocytes, endothelial & $\begin{array}{l}\text { Koga et al. 2005; Sabatier et al. 2002; } \\
\text { Nomura et al. 1995; Ogata et al. 2006; } \\
\text { Leroyer et al. 2008; Esposito et al. } 2008\end{array}$ \\
\hline End-stage renal disease & Endothelial cells & Faure et al. 2006 \\
\hline Erectile dysfunction & Endothelial cells & Esposito et al. 2008 \\
\hline Hypertension & Endothelial, monocytes, platelets & Preston et al. 2003 \\
\hline Infection & Macrophages & Bhatnagar et al. 2007 \\
\hline Lupus anticoagulant & Endothelial cells & Combes et al. 1999 \\
\hline Metabolic syndrome & Endothelial cells, tissue factor $(+)$ & Diamant et al. 2002; Arteaga et al. 2006 \\
\hline Paroxysmal nocturnal hemoglobinuria & Platelets, endothelial cells & Hugel et al. 1999; Simak et al. 2004 \\
\hline Preeclampsia & Leukocytes & Bretelle et al. 2003; Gonzalez-Quintero et al. 2004 \\
\hline Pulmonary and venous embolism & Platelets, endothelial cells & Chirinos et al. 2005; Inami et al. 2003 \\
\hline Pulmonary hypertension & Endothelial cells & Amabile et al. 2008 \\
\hline Sepsis & Leukocytes & Nieuwland et al. 2000; Joop et al. 2001 \\
\hline Sepsis & Plasma & Azevedo et al. 2007 \\
\hline Sickle cell disease & Multiple sources & Shet et al. 2003 \\
\hline Thrombotic thrombocytopenic purpura & Platelets, endothelial cells & Kelton et al. 1992; Jimenez et al. 2003 \\
\hline
\end{tabular}


Fig. 2 Possible mechanisms for the interaction of extracellular vesicles containing Hsp70 and macrophages

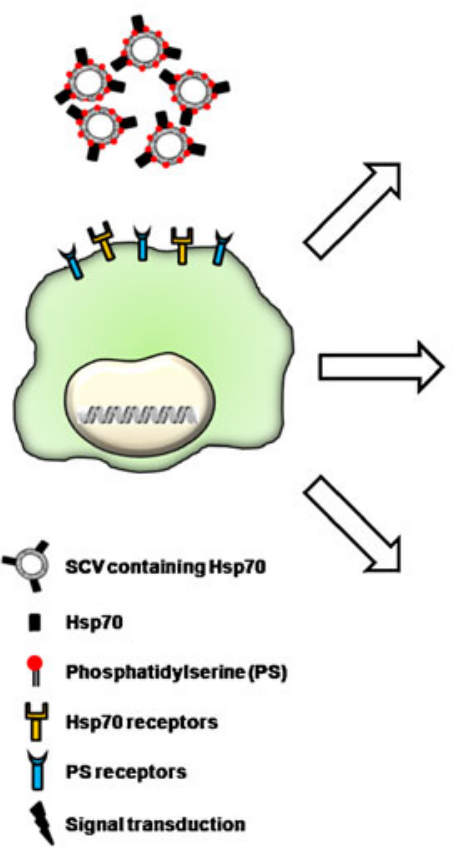

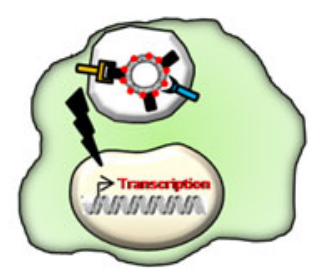
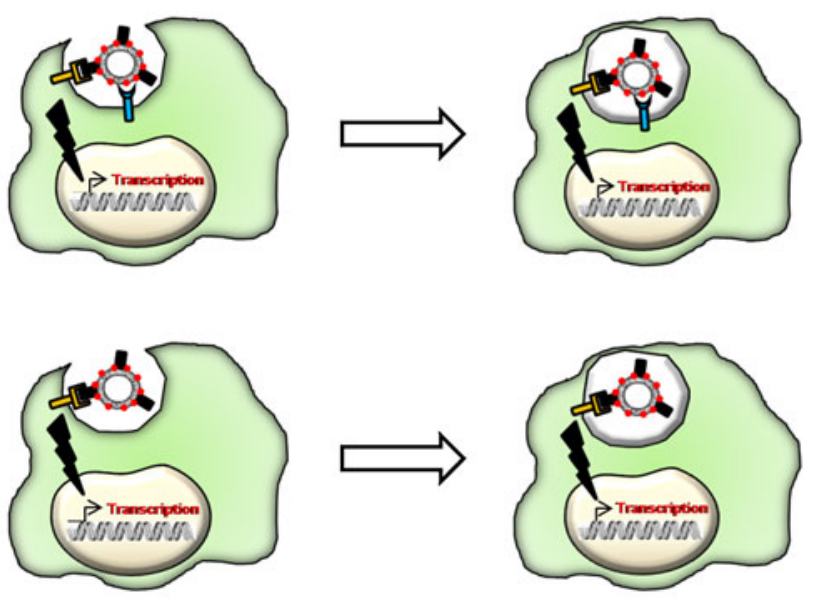

vesicles were also found to stimulate the cytotoxic capacity of NK cells (Gastpar et al. 2005). Vesicles containing Hsp70 isolated from mycobacteria-infected cells induced an inflammatory response in macrophages (O'Neill and Quah 2008). In contrast, Hsp70-membrane-associated vesicles could induce an immunosuppressive effect (Chalmin et al. 2010). Thus, it is possible that Hsp70 within export vesicles plays different roles depending on composition, vesicle source, and cell target. The mechanism for the recognition of extracellular (stress) vesicles by target cells is not known. However, it is likely that they are specifically detected by the presence of surface signals. One possibility is that extracellular vesicles lose the lipid asymmetry typical of the plasma membrane (Zwaal et al. 2005), exposing PS moieties on the surface of the vesicle. Macrophages may engulf these vesicles via surface receptors that recognize this lipid, such as Tim-4 (Miyanishi et al. 2007) and BAIl (Park et al. 2007). These receptors have been investigated in the context of uptake of apoptotic cells, which display PS on the surface as part of the cell death process. If extracellular vesicles are recognized by the presence of PS, it is likely that other components within the vesicle may be responsible for a secondary effect, such as the presence of Hsp70 (Fig. 2). Whether this effect occurs concomitantly via a surface receptor or during an endocytic process remains to be established. The other possibility is that molecules on the surface of extracellular vesicles are specifically recognized by receptors on the target cell (Fig. 2). For example, several receptors have been proposed to recognize Hsp70, including
Tlr 2 and 4 (Asea et al. 2002), CD14 (Asea et al. 2000), CD91 (Basu et al. 2001), CD40 (Becker et al. 2002; Wang et al. 2001), and scavenger receptors (Theriault et al. 2006; Facciponte et al. 2007). However, some of these observations have been controversial (Binder 2009). Whether these molecules are involved in the recognition of Hsp70-positive vesicles remains to be established. It could also be speculated that the presence of different stress signals of the vesicles may be recognized by various cell types or may trigger different responses.

\section{Concluding remarks}

The biology related to extracellular hsp is in exponential growth, leading to the discovery of more processes activated by these molecules. The multiple roles that have been associated with hsp, inside and outside cells, are remarkable. So far, we have gained a great deal of knowledge regarding the mechanisms for hsp export, which are likely to comprise multiple pathways. Similarly, it is evident that extracellular hsp come in different flavors, such as membrane-bound and membrane-free, each one with a specific systemic function. It could be envisioned that more mechanistic details for the release and function of hsp will be discovered within the next few years. It is amazing how far these disregarded initial discoveries have driven research on the stress response. However, we can expect more controversy to continue to arise, since it has been a common feature of this field. 
Acknowledgements I would like to thank Nelson Arispe for providing me with the necessary expertise to understand the complex world of lipids and membranes and for the preparation of Fig. 1, David Cauvi for providing helpful comments and the preparation of Fig. 2, Virginia Vega for her constructive criticism and long-time loyalty, and, finally, Molly Wofford for her impeccable editorial assistance.

Open Access This article is distributed under the terms of the Creative Commons Attribution Noncommercial License which permits any noncommercial use, distribution, and reproduction in any medium, provided the original author(s) and source are credited.

\section{References}

Admyre C, Grunewald J, Thyberg J, Gripenback S, Tornling G, Eklund A, Scheynius A, Gabrielsson S (2003) Exosomes with major histocompatibility complex class II and co-stimulatory molecules are present in human BAL fluid. Eur Respir J 22:578-583

Ahmed KA, Xiang J (2010) Mechanisms of cellular communication through intercellular protein transfer. J Cell Mol Med PMID. doi:10.1111/j.1582-4934.2010.01008.x

Ahn YS, Jy W, Horstman LL, Jimenez JJ (2008) Cell-derived microparticles: a mediator of inflammation in aortic valve stenosis? Thromb Haemost 99:657-658

Alder GM, Austen BM, Bashford CL, Mehlert A, Pasternak CA (1990) Heat shock proteins induce pores in membranes. Biosci Rep 10:509-518

Altmeyer A, Maki RG, Feldweg AM, Heike M, Protopopov VP, Masur SK, Srivastava PK (1996) Tumor-specific cell surface expression of the-KDEL containing, endoplasmic reticular heat shock protein gp96. Int J Cancer 69:340-349

Amabile N, Heiss C, Real WM, Minasi P, McGlothin D, Rame EJ, Grossman W, De Marco T, Yeghiazarians Y (2008) Circulating endothelial microparticle levels predict hemodynamic severity of pulmonary hypertension. Am J Respir Crit Care Med 177:1268-1275

Anand PK, Anand E, Bleck CK, Anes E, Griffiths G (1999) Exosomal Hsp70 induces a pro-inflammatory response to foreign particles including mycobacteria. PLoS ONE 5:e10136

Andrei C, Dazzi C, Lotti L, Torrisi MR, Chimini G, Rubartelli A (1999) The secretory route of the leaderless protein interleukin 1beta involves exocytosis of endolysosome-related vesicles. Mol Biol Cell 10:1463-1475

Aneja R, Odoms K, Dunsmore K, Shanley TP, Wong HR (2006) Extracellular heat shock protein-70 induces endotoxin tolerance in THP-1 cells. J Immunol 177:7184-7192

Arap MA, Lahdenranta J, Mintz PJ, Hajitou A, Sarkis AS, Arap W, Pasqualini R (2004) Cell surface expression of the stress response chaperone GRP78 enables tumor targeting by circulating ligands. Cancer Cell 6:275-284

Arispe N, De Maio A (2000) ATP and ADP modulate a cation channel formed by $\mathrm{Hsc} 70$ in acidic phospholipid membranes. J Biol Chem 275:30839-30843

Arispe N, Rojas E, Pollard HB (1993) Alzheimer disease amyloid $\beta$ protein forms calcium channels in bilayer membranes: blockade by tromethamine and aluminum. Proc Natl Acad Sci USA 90:567-571

Arispe N, Rojas E, Genge BR, Wu LNY, Wuthier RE (1996) Similarity in calcium chennel activity of annexin $\mathrm{V}$ and matrix vesicles in planar lipid bilayers. Biophys J 71:1764-1775

Arispe N, Doh M, De Maio A (2002) Lipid interaction differentiates the constitutive and stress-induced heat shock proteins Hsc70 and Hsp70. Cell Stress Chaperones 7:330-338
Arispe N, Doh M, Simakova O, Kurganov B, De Maio A (2004) Hsc70 and Hsp70 interact with phosphatidylserine on the surface of $\mathrm{PC} 12$ cells resulting in a decrease of viability. FASEB J 18:1636-1645

Arteaga RB, Chirinos JA, Soriano AO, Jy W, Horstman L, Jimenez JJ, Mendez A, Ferreira A, de Marchena E, Ahn YS (2006) Endothelial microparticles and platelet and leukocyte activation in patients with the metabolic syndrome. Am J Cardiol 98:70-74

Asea A, Kraeft SK, Kurt-Jones EA, Stevenson MA, Chen LB, Finberg RW, Koo GC, Calderwood SK (2000) HSP70 stimulates cytokine production through a CD14-dependant pathway, demonstrating its dual role as a chaperone and cytokine. Nat Med 6:435-442

Asea A, Rehli M, Kabingu E, Boch JA, Bare O, Auron PE, Stevenson MA, Calderwood SK (2002) Novel signal transduction pathway utilized by extracellular HSP70: role of toll-like receptor (TLR) 2 and TLR4. J Biol Chem 277:15028-15034

Azevedo LC, Janiszewski M, Pontieri V, Pedro Mde A, Bassi E, Tucci PJ, Laurindo FR (2007) Platelet-derived exosomes from septic shock patients induces myocardial dysfunction. Crit Care 11: R120

Azuma K, Shichijo S, Takedatsu H, Komatsu N, Sawamizu H, Itoh K (2003) Heat shock cognate protein 70 encodes antigenic epitopes recognised by HLA-B4601-restricted cytotoxic T lymphocytes from cancer patients. Br J Cancer 89:1079-1085

Basu S, Binder RJ, Suto R, Anderson KM, Srivastava PK (2000) Necrotic but not apoptotic cell death releases heat shock proteins, which deliver a partial maturation signal to dendritic cells and activate the NF-kappa B pathway. Int Immunol 12:1539-1546

Basu S, Binder RJ, Ramalingam T, Srivastava PK (2001) CD91 is a common receptor for heat shock proteins gp96, hsp90, hsp 70 , and calreticulin. Immunity 14:303-313

Bausero MA, Page DT, Osinaga E, Asea A (2004) Surface expression of Hsp25 and Hsp72 differentially regulates tumor growth and metastasis. Tumour Biol 25:243-251

Bausinger H, Lipsker D, Hanau D (2002) Heat-shock proteins as activators of the innate immune system. Trends Immunol 23:342-343

Becker T, Hartl FU, Wieland F (2002) CD40, an extracellular receptor for binding and uptake of Hsp70-peptide complexes. J Cell Biol 158:1277-1285

Belles C, Kuhl A, Nosheny R, Carding SR (1999) Plasma membrane expression of heat shock protein 60 in vivo in response to infection. Infect Immun 67:4191-4200

Bendz H, Marincek BC, Momburg F, Ellwart JW, Issels RD, Nelson PJ, Noessner E (2008) Calcium signaling in dendritic cells by human or mycobacterial Hsp70 is caused by contamination and is not required for Hsp70-mediated enhancement of crosspresentation. J Biol Chem 283:26477-26483

Bernal-Mizrachi L, Jy W, Fierro C, MacDonough R, Velazques HH, Purow J, Jimenez JJ, Horstman LL, Ferreira A, de Marchena E, Ahn YS (2004) Endothelial microparticles correlate with highrisk angiographic lesions in acute coronary syndromes. Int $\mathrm{J}$ Cardiol 97:439-446

Bhatnagar S, Shinagawa K, Castellino FJ, Schorey JS (2007) Exosomes released from macrophages infected with intracellular pathogens stimulate a proinflammatory response in vitro and in vivo. Blood 110:3234-3244

Binder RJ (2009) CD40-independent engagement of mammalian hsp70 by antigen-presenting cells. J Immunol 182:6844-6850

Blanchard N, Lankar D, Faure F, Regnault A, Dumont C, Raposo G, Hivroz C (2002) TCR activation of human T cells induces the production of exosomes bearing the TCR/CD3/zeta complex. $\mathrm{J}$ Immunol 168:3235-3241

Botzler C, Li G, Issels RD, Multhoff G (1998) Definition of extracellular localized epitopes of Hsp70 involved in an NK immune response. Cell Stress Chaperones 3:6-11 
Bretelle F, Sabatier F, Desprez D, Camoin L, Grunebaum L, Combes V, D'Ercole C, Dignat-George F (2003) Circulating microparticles: a marker of procoagulant state in normal pregnancy and pregnancy complicated by preeclampsia or intrauterine growth restriction. Thromb Haemost 89:486-492

Broquet AH, Thomas G, Masliah J, Trugnan G, Bachele M (2003) Expression of the molecular chaperone Hsp70 in detergentresistant microdomains correlates with its membrane delivery and release. J Biol Chem 278:21601-21606

Brown DA, London E (2000) Structure and function of sphingolipidand cholesterol-rich membrane rafts. J Biol Chem 275:1722117224

Bukau B, Weissman J, Horwich A (2006) Molecular chaperones and protein quality control. Cell 125:443-451

Caby MP, Lankar D, Vincendeau-Scherrer C, Raposo G, Bonnerot C (2005) Exosomal-like vesicles are present in human blood plasma. Int Immunol 17:879-887

Camins A, Diez-Fernandez C, Prieto P (1999) Cell-surface expression of heat shock proteins in dog neutrophils after oxidative stress. Toxicol In Vitro 13:437-443

Chalmin F, Ladoire S, Mignot G, Vincent J, Bruchard M et al (2010) Membrane-associated Hsp72 from tumor-derived exosomes mediates STAT3-dependent immunosuppressive function of mouse and human myeloid-derived suppressor cells. J Clin Invest 120:457-471

Chaput N, Flament C, Viaud S, Taieb J, Roux S et al (2006) Dendritic cell derived-exosomes: biology and clinical implementations. J Leukocyte Biol 80:471-478

Chen S, Bawa D, Besshoh S, Gurd JW, Brown IR (2005) Association of heat shock proteins and neuronal membrane components with lipid rafts from the rat brain. J Neurosci Res 81:522-529

Chirinos JA, Heresi GA, Velasquez H, Jimenez JyW, JJ AE et al (2005) Elevation of endothelial microparticles, platelets, and leukocyte activation in patients with venous thromboembolism. J Am Coll Cardiol 45:1467-1471

Cid C, Regidor I, Poveda PD, Alcazar A (2009) Expression of heat shock protein 90 at the cell surface in human neuroblastoma cells. Cell Stress Chaperones 14:321-327

Clayton A, Turkes A, Navabi H, Mason MD, Tabi Z (2005) Induction of heat shock proteins in B-cell exosomes. J Cell Sci 118:3631-3638

Combes V, Simon AC, Grau GE, Arnoux D, Camoin L, Sabatier F, Mutin M, Sanmarco M, Sampol J, Dignat-George F (1999) In vitro generation of endothelial microparticles and possible prothrombotic activity in patients with lupus anticoagulant. J Clin Invest 104:93-102

Conde-Vancells J, Rodriguez-Suarez E, Embade N, Gill D, Matthiesen R, Valle M, Elortza F, Lu SC, Mato JM, Falcon-Perez JM (2008) Characterization and comprehensive proteome profiling of exosomes secreted by hepatocytes. J Proteome Res 7:5157-5166

Davis DM (2007) Intercellular transfer of cell-surface proteins is common and can affect many stages of an immune response. Nat Rev 7:238-243

de Gassart A, Geminard C, Fevrier B, Raposo G, Vidal M (2003) Lipid raft-associated protein sorting in exosomes. Blood 102:4336-4344

De Maio A (1999) Heat shock proteins: Facts, thoughts, and dreams. Shock 11:1-12

De Maio A, Vega V, Contreras JE (2002) Gap junctions, homeostasis and injury. J Cell Physiol 191:269-282

del Conde I, Shrimpton CN, Thiagarajan P, Lopez JA (2005) Tissuefactor-bearing microvesicles arise from lipid rafts and fuse with activated platelets to initiate coagulation. Blood 106:1604-1611

Delpino A, Castelli M (2002) The $78 \mathrm{kDa}$ glucose-regulated protein (GRP78/BIP) is expressed on the cell membrane, is released into cell culture medium and is also present in human peripheral circulation. Biosci Rep 22:407-420
Diamant M, Nieuwland R, Pablo RF, Sturk A, Smit JW, Radder JK (2002) Elevated numbers of tissue-factor exposing microparticles correlate with components of the metabolic syndrome in uncomplicated type 2 diabetes mellitus. Circulation 106:2442-2447

Diehl P, Nagy F, Sossong V, Helbing T, Beyersdorf F, Olschewski M, Bode C, Moser M (2008) Increased levels of circulating microparticles in patients with severe aortic valve stenosis. Thromb Haemost 99:711-719

Dybdahl B, Slordahl SA, Waage A, Kierulf P, Espevik T, Sundan A (2005) Myocardial ischaemia and the inflammatory response: release of heat shock protein 70 after myocardial infarction. Heart 91:299-304

Eder C (2008) Mechanisms of interleukin-1beta release. Immunobiology 214:543-553

Esposito K, Ciotola M, Giugliano F, Sardelli L, Giugliano F, Maiorino MI, Beneduce F, De Sio M, Giugliano D (2008) Phenotypic assessment of endothelial microparticles in diabetic and nondiabetic men with erectile dysfunction. J Sexual Med 5:1436-1442

Evdonin AL, Martynova MG, Bystrova OA, Guzhova I, Margulis B, Medvedeva N (2006) The release of Hsp70 from A431 carcinoma cells is mediated by secretory-like granules. Eur $\mathrm{J}$ Cell Biol 85:443-455

Facciponte JG, Wang XY, Subjeck JR (2007) Hsp110 and Grp170, members of the Hsp70 superfamily, bind to scavenger receptor-A and scavenger receptor expressed by endothelial cells-I. Eur J Immunol 37:2268-2279

Farkas B, Hantschel M, Magyarlaki M, Becker B, Scherer K et al (2003) Heat shock protein 70 membrane expression and melanoma-associated marker phenotype in primary and metastatic melanoma. Melanoma Res 13:147-152

Faure O, Graff-Dubois S, Bretaudeau L, Derre L, Gross DA et al (2004) Inducible Hsp70 as target of anticancer immunotherapy: Identification of HLA-A*0201-restricted epitopes. Int J Cancer 108:863-870

Faure V, Dou L, Sabatier F, Cerini C, Sampol J, Berland Y, Brunet P, Dignat-George F (2006) Elevation of circulating endothelial microparticles in patients with chronic renal failure. J Thromb Haemost 4:566-573

Ferrarini M, Heltai S, Zocchi MR, Rugarli C (1992) Unusual expression and localization of heat-shock proteins in human tumor cells. Int J Cancer 51:613-619

Fouchaq B, Benaroudj N, Ebel C, Ladjimi MM (1999) Oligomerization of the $17-\mathrm{kDa}$ peptide-binding domain of the molecular chaperone HSC70. Eur J Biochem/FEBS 259:379-384

Galloway E, Shin T, Huber N, Eismann T, Kuboki S, Schuster R, Blanchard J, Wong HR, Lentsch AB (2008) Activation of hepatocytes by extracellular heat shock protein 72. Am J Physiol Cell Physiol 295:C514-520

Ganter MT, Ware LB, Howard M, Roux J, Gartland B, Matthay MA, Fleshner M, Pittet JF (2006) Extracellular heat shock protein 72 is a marker of the stress protein response in acute lung injury. Am J Physiol Lung Cell Mol Physiol 291:L354-L631

Gao B, Tsan MF (2003) Endotoxin contamination in recombinant human heat shock protein 70 (Hsp70) preparation is responsible for the induction of tumor necrosis factor alpha release by murine macrophages. J Biol Chem 278:174-179

Gao B, Eisenberg E, Greene L (1996) Effect of constitutive 70-kDa heat shock protein polymerization on its interaction with protein substrate. J Biol Chem 271:16792-16797

Gardella S, Andrei C, Ferrera D, Lotti LV, Torrisi MR, Bianchi ME, Rubartelli A (2002) The nuclear protein HMGB1 is secreted by monocytes via a non-classical, vesicle-mediated secretory pathway. EMBO Rep 3:995-1001

Gastpar R, Gross C, Rossbacher L, Ellwart J, Riegger J, Multhoff G (2004) The cell surface-localized heat shock protein 70 epitope TKD induces migration and cytolytic activity selectively in human NK cells. J Immunol 172:972-980 
Gastpar R, Gehrmann M, Bausero MA, Asea A, Gross C, Schroeder JA, Multhoff G (2005) Heat shock protein 70 surface-positive tumor exosomes stimulate migratory and cytolytic activity of natural killer cells. Cancer Res 65:5238-5247

Gatti JL, Metayer S, Belghazi M, Dacheux F, Dacheux JL (2005) Identification, proteomic profiling, and origin of ram epididymal fluid exosome-like vesicles. Biol Reprod 7:1452-1465

Gehrmann M, Schmetzer H, Eissner G, Haferlach T, Hiddemann W, Multhoff G (2003) Membrane-bound heat shock protein 70 (Hsp70) in acute myeloid leukemia: a tumor specific recognition structure for the cytolytic activity of autologous NK cells. Haematologica 88:474-476

Gehrmann M, Liebisch G, Schmitz G, Anderson R, Steinem C, De Maio A, Pockley G, Multhoff G (2008) Tumor-specific Hsp70 plasma membrane localization is enabled by the glycosphingolipid Gb3. PLoS ONE 3:e1925

Gelderman MP, Simak J (2008) Flow cytometric analysis of cell membrane microparticles. Methods Mol Biol 484:79-93

Genth-Zotz S, Bolger AP, Kalra PR, von Haehling S, Doehner W, Coats A, Volk HD, Anker SD (2004) Heat shock protein 70 in patients with chronic heart failure: relation to disease severity and survival. Int J Cardiol 96:397-401

Giffard RG, Han RQ, Emery JF, Duan M, Pittet JF (2008) Regulation of apoptotic and inflammatory cell signaling in cerebral ischemia: the complex roles of heat shock protein 70. Anesthesiology 109:339-348

Gonzalez-Quintero VH, Smarkusky LP, Jimenez JJ, Mauro L, Jy W, Horstman LL, O'Sullivan MJ, Ahn YS (2004) Elevated plasma endothelial microparticles: preeclampsia versus gestational hypertension. Am J Obstet Gynecol 191:1418-1424

Gronthos S, Zannettino AC, Graves SE, Ohta S, Hay SJ, Simmons PJ (1999) Differential cell surface expression of the STRO-1 and alkaline phosphatase antigens on discrete developmental stages in primary cultures of human bone cells. J Bone Miner Res 14:47-56

Hantschel M, Pfister K, Jordan A, Scholz R, Andreesen R, Schmitz G, Schmetzer H, Hiddemann W, Multhoff G (2000) Hsp70 plasma membrane expression on primary tumor biopsy material and bone marrow of leukemic patients. Cell Stress Chaperones $5: 438-442$

Harding C, Heuser J, Stahl P (1983) Receptor-mediated endocytosis of transferrin and recycling of the transferrin receptor in rat reticulocytes. J Cell Biol 97:329-339

Hartl FU, Hayer-Hartl M (2009) Converging concepts of protein folding in vitro and in vivo. Nat Struct Mol Biol 16:574-581

Hecker JG, McGarvey M (2010) Heat shock proteins as biomarkers for the rapid detection of brain and spinal cord ischemia: a review and comparison to other methods of detection in thoracic aneurysm repair. Cell Stress Chaperones, epub Aug. 30

Hegmans JP, Bard MP, Hemmes A, Luider TM, Kleijmeer M, Prins JB, Zitvogel L, Burgers SA, Hoogsteden H, Lambrecht B (2004) Proteomic analysis of exosomes secreted by human mesothelioma cells. Am J Pathol 164:1807-1815

Hightower LE, Guidon PT (1989) Selective release from cultured mammalian cells of heat-shock (stress) proteins that resemble glia-axon transfer proteins. J Cell Physiol 138:257-266

Hirsh MI, Hashiguchi N, Chen Y, Yip L, Junger WG (2006) Surface expression of HSP72 by LPS-stimulated neutrophils facilitates gammadeltaT cell-mediated killing. Eur J Immunol 36:712-721

Horstman LL, Jy W, Jimenez JJ, Ahn YS (2004) Endothelial microparticles as markers of endothelial dysfunction. Front Biosci 9:1118-1135

Horvath I, Multhoff G, Sonnleitner A, Vigh L (2008) Membraneassociated stress proteins: more than simply chaperones. Biochim Biophys Acta 1778:1653-1664

Hristov M, Erl W, Linder S, Weber PC (2004) Apoptotic bodies from endothelial cells enhance the number and initiate the differenti- ation of human endothelial progenitor cells in vitro. Blood 104:2761-2766

Hugel B, Socie G, Vu T, Toti F, Gluckman E, Freyssinet JM, Scrobohaci ML (1999) Elevated levels of circulating procoagulant microparticles in patients with paroxysmal nocturnal hemoglobinuria and aplastic anemia. Blood 93:3451-3456

Hugel B, Martinez MC, Kunzelmann C, Freyssinet JM (2005) Membrane microparticles: two sides of the coin. Physiology 20:22-27

Hunter-Lavin C, Davies EL, Bacelar MM, Marshall MJ, Andrew SM, Williams JH (2004) Hsp70 release from peripheral blood mononuclear cells. Biochem Biophys Res Commun 324:511-517

Inami N, Nomura S, Kikuchi H, Kajiura T, Yamada K et al (2003) Pselectin and platelet-derived microparticles associated with monocyte activation markers in patients with pulmonary embolism. Clin Appl Thromb/Hemost 9:309-316

Jimenez JJ, Jy W, Mauro LM, Horstman LL, Soderland C, Ahn YS (2003) Endothelial microparticles released in thrombotic thrombocytopenic purpura express von Willebrand factor and markers of endothelial activation. Br J Haematol 123:896902

Johnstone RM (2006) Exosomes biological significance: a concise review. Blood Cells Mol Dis 36:315-321

Joop K, Berckmans RJ, Nieuwland R, Berkhout J, Romijn FP, Hack CE, Sturk A (2001) Microparticles from patients with multiple organ dysfunction syndrome and sepsis support coagulation through multiple mechanisms. Thromb Haemost $85: 810-820$

Kampinga HH, Hageman J, Vos MJ, Kubota H, Tanguay RM, Bruford EA, Cheetham ME, Chen B, Hightower LE (2009) Guidelines for the nomenclature of the human heat shock proteins. Cell Stress Chaperones 14:105-111

Kaur J, Das SN, Srivastava A, Ralhan R (1998) Cell surface expression of $70 \mathrm{kDa}$ heat shock protein in human oral dysplasia and squamous cell carcinoma: correlation with clinicopathological features. Oral Oncol 34:93-98

Keller S, Rupp C, Stoeck A, Runz S, Fogel M, Lugert S, Hager HD, Abdel-Bakky MS, Gutwein P, Altevogt P (2007) CD24 is a marker of exosomes secreted into urine and amniotic fluid. Kidney Int 72:1095-1102

Kelton JG, Warkentin TE, Hayward CP, Murphy WG, Moore JC (1992) Calpain activity in patients with thrombotic thrombocytopenic purpura is associated with platelet microparticles. Blood 80:2246-2251

Kern J, Untergasser G, Zenzmaier C, Sarg B, Gastl B, Gunsilius E, Steurer M (2009) GRP-78 secreted by tumor cells blocks the antiangiogenic activity of bortezomib. Blood 114:3960-3967

Kleinjung T, Arndt O, Feldmann HJ, Bockmuhl U, Gehrmann M et al (2003) Heat shock protein 70 (Hsp70) membrane expression on head-and-neck cancer biopsy-a target for natural killer (NK) cells. Int J Radiat Oncol Biol Phys 57:820-826

Koga H, Sugiyama S, Kugiyama K, Wantanabe K, Fukushima H, Tanaka T, Sakamoto T, Yoshimura M, Jinnouchi H, Ogawa H (2005) Elevated levels of VE-cadherin-positive endothelial microparticles in patients with type 2 diabetes mellitus and coronary artery disease. J Am College Cardiol 45:1622-1630

Kovalchin JT, Wang R, Wagh MS, Azoulay J, Sanders M, Chandawarkar RY (2006) In vivo delivery of heat shock protein 70 accelerates wound healing by up-regulating macrophage-mediated phagocytosis. Wound Repair Regen 14:129-137

Lancaster GI, Febbraio MA (2005) Exosome-dependent trafficking of HSP70: a novel secretory pathway for cellular stress proteins. J Biol Chem 280:23349-23355

Lasunskaia EB, Fridlianskaia I, Arnholdt AV, Kanashiro M, Guzhova I, Margulis B (2010) Sub-lethal heat shock induces plasma 
membrane translocation of $70-\mathrm{kDa}$ heat shock protein in viable, but not in apoptotic, U-937 leukaemia cells. APMIS 118:179187

Leroyer AS, Tedgui A, Boulanger CM (2008) Microparticles and type 2 diabetes. Diabetes Metab 34:S27-S32

Liao WS, Wu MS, Wang HP, Tren YW, Lin JT (2009) Serum heat shock protein 27 is increased in chronic pancreatititis and pancreatic cancer. Pancreas 38:422-426

Lindquist S, Craig EA (1988) The heat-shock proteins. Annu Rev Genet 22:316-377

Liu C, Bhattacharjee G, Boisvert W, Dilley R, Edgington T (2003) In vivo interrogation of the molecular display of atherosclerotic lesion surfaces. Am J Pathol 163:1859-1871

Liu S, Stolz DB, Sappington PL, Macias CA, Killeen M, Tenhunen J, Delude R, Fink M (2006) HMGB1 is secreted by immunostimulated enterocytes and contributes to cytomix-induced hyperpermeability of Caco-2 monolayers. Am J Physiol 290:C990-999

Lopez JA, del Conde I, Shrimpton CN (2005) Receptors, rafts, and microvesicles in thrombosis and inflammation. J Thromb Haemost 3:1737-1744

MacKenzie A, Wilson HL, Kiss-Toth E, Dower SK, North R, Suprenant A (2001) Rapid secretion of interleukin-1beta by microvesicle shedding. Immunity 15:825-835

Mallat Z, Benamer H, Hugel B, Benessiano J, Steg PG, Freyssinet J, Tedgui A (2000) Elevated levels of shed membrane microparticles with procoagulant potential in the peripheral circulating blood of patients with acute coronary syndromes. Circulation 101:841-843

Mambula SS, Calderwood SK (2006) Heat shock protein 70 is secreted from tumor cells by a nonclassical pathway involving lysosomal endosomes. J Immunol 177:7849-7857

Mathew A, Bell A, Johnstone RM (1995) Hsp-70 is closely associated with the transferrin receptor in exosomes from maturing reticulocytes. Biochem J 308:823-830

McCready J, Sims JD, Chan D, Jay DG (2010) Secretion of extracellular hsp90alpha via exosomes increases cancer cell motility: a role for plasminogen activation. BMC Cancer 10:294

Merendino AM, Bucchieri F, Campanella C, Marciano V, Ribbene A et al (2010) Hsp60 is actively secreted by human tumor cells. PLoS ONE 5:e9247

Meziani F, Tesse A, Andriantsitohaina R (2008) Microparticles are vectors of paradoxical information in vascular cells including the endothelium: role in health and diseases. Pharmacol Rep 60:7584

Mills DR, Haskell MD, Callanan HM, Flanagan D, Brilliant K, Yang D, Hixson D (2010) Monoclonal antibody to novel cell surface epitope on Hsc70 promotes morphogenesis of bile ducts in newborn rat liver. Cell Stress Chaperones 15:39-53

Miyanishi M, Tada K, Koike M, Uchiyama Y, Kitamura T, Nagata S (2007) Identification of Tim4 as a phosphatidylserine receptor. Nature 450:435-439

Molvarec A, Prohaszka Z, Nagy B, Szaley J, Fust G, Karadi I, Rigo J Jr (2006) Association of elevated serum heat-shock protein 70 concentration with transient hypertension of pregnancy, preeclampsia and superimposed preeclampsia: a case-control study. J Hum Hypertens 20:780-786

Morimoto RI (1991) Heat shock: the role of transient inducible responses in cell damage, transformation and differentiation. Cancer Cells 3:295-301

Mostefai HA, Andriantsitohaina R, Martinez MC (2008) Plasma membrane microparticles in angiogenesis: role in ischemic diseases and in cancer. Physiol Res Acad Sci Bohemoslov $57: 311-320$

Multhoff G (2007) Heat shock protein 70 (Hsp70): membrane location, export and immunological relevance. Methods $43: 229-237$
Multhoff G, Hightower LE (1996) Cell surface expression of heat shock proteins and the immune response. Cell Stress Chaperones $1: 167-176$

Multhoff G, Botzler C, Wiesnet M, Muller E, Meier T, Wilmanns W (1995) A stress-inducible $72 \mathrm{kDa}$ heat shock protein (Hsp72) is expressed on the surface of human tumor cells but not on normal cells. Int J Cancer 61:272-279

Nickel W, Seedorf M (2008) Unconventional mechanisms of protein transport to the cell surface of eukaryotic cells. Annu Rev Cell Dev Biol 24:287-308

Nieuwland R, Berckmans RJ, Rotteveel-Eijkman RC, Maquelin K, Roozendaal K, Jansen P, ten Have K, Eijsman L, Hack CE, Sturk A (1997) Cell-derived microparticles generated in patients during cardiopulmonary bypass are highly procoagulant. Circulation 96:3534-3541

Nieuwland R, Berckmans RJ, McGregor S, Boing A, Romijn F, Westendorp R, Hack CE, Sturk A (2000) Cellular origin and procoagulant properties of microparticles in meningococcal sepsis. Blood 95:930-935

Njemini R, Lambert M, Demanet C, Mets T (2003) Elevated serum heat-shock protein 70 levels in patients with acute infection: use of an optimized enzyme-linked immunosorbent assay. Scand J Immunol 58:664-669

Njemini R, Demanet C, Mets T (2004) Inflammatory status as an important determinant of heat shock protein 70 serum concentrations during aging. Biogerontology 5:31-38

Nomura S, Suzuki M, Katsura K, Xie G, Miyazaki Y, Miyake T, Kido H, Kagawa H, Fukuhara S (1995) Platelet-derived microparticles may influence the development of atherosclerosis in diabetes mellitus. Atherosclerosis 116:235-240

Nomura S, Imamura A, Okuno M, Kamiyama Y, Fujimura Y, Ikeda Y, Fukuhara S (2000) Platelet-derived microparticles in patients with arteriosclerosis obliterans: enhancement of high shear-induced microparticle generation by cytokines. Thromb Res 98:257-268

Noonan EJ, Fournier G, Hightower LE (2008) Surface expression of Hsp70B' in response to proteasome inhibition in human colon cells. Cell Stress Chaperones 13:105-110

Nylandsted J, Gyrd-Hansen M, Danielewicz A, Fehrenbacher N, Lademann U, Hoyer-Hansen M, Weber E, Multhoff G, Rohde M, Jaattela M (2004) Heat shock protein 70 promotes cell survival by inhibiting lysosomal membrane permeabilization. J Exp Med 200:425-435

Ogata H, Tokuyama K, Nagasaka S, Ando A, Kusaka I et al (2006) Long-range negative correlation of glucose dynamics in humans and its breakdown in diabetes mellitus. Am J Physiol 291: R1638-R1643

Oglesbee MJ, Herdman AV, Passmore GG, Hoffman WH (2005) Diabetic ketoacidosis increases extracellular levels of the major inducible $70-\mathrm{kDa}$ heat shock protein. Clin Biochem 38:900-904

O’Neill HC, Quah BJ (2008) Exosomes secreted by bacterially infected macrophages are proinflammatory. Sci Signal 1:pe8

Ostrowski M, Carmo NB, Krumeich S, Fanget I, Raposo G et al (2010) Rab72a and Rab27b control different steps of the exosomes secretion pathway. Nat Cell Bio 12:19-30

Pan BT, Teng K, Wu C, Adam M, Johnstone RM (1985) Electron microscopic evidence for externalization of the transferrin receptor in vesicular form in sheep reticulocytes. J Cell Biol 101:942-948

Park D, Tosello-Trampont AC, Elliott MR, Lu M, Haney L, Ma Z, Klibanov A, Mandell J, Ravichandran K (2007) BAI1 is an engulfment receptor for apoptotic cells upstream of the ELMO/ Dock180/Rac module. Nature 450:430-434

Pilzer D, Fishelson Z (2005) Mortalin/GRP75 promotes release of membrane vesicles from immune attacked cells and protection from complement-mediated lysis. Int Immunol 17:1239-1248 
Pittet JF, Lee H, Morabito D, Howard M, Welch W, Mackersie R (2002) Serum levels of Hsp 72 measured early after trauma correlate with survival. J Trauma 52:611-617

Pockley AG, Shepherd J, Corton JM (1998) Detection of heat shock protein 70 (Hsp70) and anti-Hsp70 antibodies in the serum of normal individuals. Immunol Invest 27:367-377

Pockley AG, Muthana M, Calderwood SK (2008) The dual immunoregulatory roles of stress proteins. Trends Biochem Sci 33:71-79

Prado N, Marazuela EG, Segura E, Fernandez-Garcia H, Villalba M, Thery C, Rodriguez R, Batanero E (2008) Exosomes from bronchoalveolar fluid of tolerized mice prevent allergic reaction. J Immunol 181:1519-1525

Preston RA, Jy W, Jimenez JJ, Mauro M, Horstman L, Valle M, Aime G, Ahn YS (2003) Effects of severe hypertension on endothelial and platelet microparticles. Hypertension 41:211-217

Raposo G, Nijman HW, Stoorvogel W, Liejendekker R, Harding C, Melief C, Geuze H (1996) B lymphocytes secrete antigenpresenting vesicles. J Exp Med 183:1161-1172

Raposo G, Tenza D, Mecheri S, Peronet R, Bonnerot C, Desaymard C (1997) Accumulation of major histocompatibility complex class II molecules in mast cell secretory granules and their release upon degranulation. Mol Biol Cell 8:2631-2645

Ritossa F (1996) Discovery of the heat shock response. Cell Stress Chaperones 1:97-98

Robert J, Menoret A, Cohen N (1999) Cell surface expression of the endoplasmic reticular heat shock protein gp96 is phylogenetically conserved. J Immunol 163:4133-4139

Rojas E, Arispe N, Haigler HT, Burns AL, Pollard HB (1992) Identification of annexins as calcium channels in biological membranes. Bone Miner 17:214-218

Rossig L, Haendeler J, Mallat Z, Hugel B, Freyssinet J, Tedgui A, Dimmeler S, Zeiher A (2000) Congestive heart failure induces endothelial cell apoptosis: protective role of carvedilol. J Am College Cardiol 36:2081-2089

Sabatier F, Darmon P, Hugel B, Combes V, Sanmarco M et al (2002) Type 1 and type 2 diabetic patients display different patterns of cellular microparticles. Diabetes 51:2840-2845

Sadallah S, Eken C, Schifferli JA (2008) Erythrocyte-derived ectosomes have immunosuppressive properties. J Leukoc Biol 84:1316-1325

Savina A, Vidal M, Colombo MI (2002) The exosomes pathway in K562 cells is regulated by Rab11. J Cell Sci 115:2505-1515

Savina A, Furlan M, Vidal M, Colombo MI (2003) Exosome release is regulated by a calcium-dependent mechanism in K562 cells. J Biol Chem 278:20083-20090

Schilling D, Gehrmann M, Steinem C, De Maio A, Pockley AG, Abend M, Molls M, Multhoff G (2009) Binding of heat shock protein 70 to extracellular phosphatidylserine promotes killing of normoxic and hypoxic tumor cells. FASEB J 23:2467-2477

Schlossman DM, Schmid SL, Brael WA, Rothman JE (1984) An enzyme that removes clathrin coats: purification of an uncoating ATPase. J Cell Biol 99:723-733

Schorey JS, Bhatnagar S (2008) Exosome function: from tumor immunology to pathogen biology. Traffic 9:871-881

Sedlackova L, Nguyen TT, Zlacka D, Sosna A, Hromadnikova I (2009) Cell surface and relative mRNA expression of heat shock protein 70 in human synovial cells. Autoimmunity 42:17-24

Shet AS, Aras O, Gupta K, Hass M, Rausch D, Saba N, Koopmeiners L, Key N, Hebbel R (2003) Sickle blood contains tissue factorpositive microparticles derived from endothelial cells and monocytes. Blood 102:2678-2683

Sidera K, Patsavoudi E (2008) Extracellular HSP90: conquering the cell surface. Cell Cycle 7:1564-1568

Simak J, Holada K, Risitano AM, Zivny J, Young N, Vostal J (2004) Elevated circulating endothelial membrane microparticles in paroxysmal nocturnal haemoglobinuria. $\mathrm{Br} \mathrm{J}$ Haematol 125:804-813

Simak J, Gelderman MP, Yu H, Wright V, Baird AE (2006) Circulating endothelial microparticles in acute ischemic stroke: a link to severity, lesion volume and outcome. J Thromb Haemost 4:1296-1302

Simpson RJ, Jensen SS, Lim JW (2008) Proteomic profiling of exosomes: current perspectives. Proteomics 8:4083-4099

Smalley DM, Ley K (2008) Plasma-derived microparticles for biomarker discovery. Clin Lab 54:67-79

Srivastava PK (1997) Purification of heat shock protein-peptide complexes for use in vaccination against cancers and intracellular pathogens. Methods 12:165-171

Sugawara S, Kawano T, Omoto T, Hosono N, Tatsuta T, Nitta K (2009) Binding of Silurus asotus lectin to Gb3 on Raji cells causes disappearance of membrane-bound form of HSP70. Biochim Biophys Acta 1790:101-109

Takemoto H, Yoshimori T, Yamamoto A, Miyata Y, Yahara I, Inoue K, Tashiro Y (1992) Heavy chain binding protein (BiP/GRP78) and endoplasmin are exported from the endoplasmic reticulum in rat exocrine pancreatic cells, similar to protein disulfide-isomerase. Arch Biochem Biophys 296:129-136

Tani F, Ohno M, Furukawa Y, Sakamoto M, Masuda S, Kitabatake N (2009) Surface expression of a C-terminal alpha-helix region in heat shock protein 72 on murine LL/2 lung carcinoma can be recognized by innate immune sentinels. Mol Immunol 46:13261339

Theriault JR, Adachi H, Calderwood SK (2006) Role of scavenger receptors in the binding and internalization of heat shock protein 70. J Immunol 177:8604-8611

Thery C, Regnault A, Garin J, Wolfers J, Zitvogel L, RicciardiCastagnoli P, Raposo G, Amigorena S (1999) Molecular characterization of dendritic cell-derived exosomes. Selective accumulation of the heat shock protein hsc73. J Cell Biol 147:599-610

Thery C, Ostrowski M, Segura E (2009) Membrane vesicles as conveyors of immune responses. Nat Rev 9:581-593

Triantafilou M, Miyake K, Golenbock DT, Triantafilou K (2002) Mediators of innate immune recognition of bacteria concentrate in lipids rafts and facilitate lipopolysaccharide-induced cell activation. J Cell Sci 115:26032611

Tsutsumi S, Neckers L (2007) Extracellular heat shock protein 90: a role for a molecular chaperone in cell motility and cancer metastasis. Cancer Sci 98:1536-1539

Tytell M, Greenberg SG, Lasek RJ (1986) Heat shock-like protein is transferred from glia to axon. Brain Res 363:161-164

Vabulas RM, Ahmad-Nejad P, Ghose S, Kirschning C, Issels R, Wagner H (2002) HSP70 as endogenous stimulus of the Toll/interleukin-1 receptor signal pathway. J Biol Chem 277:15107-15112

Vega VL, Rodriguez-Silva M, Frey T, Gehrmann M, Diaz JC, Steinem C, Multhoff G, Arispe N, De Maio A (2008) Hsp70 translocates into the plasma membrane after stress and is released into the extracellular environment in a membrane-associated form that activates macrophages. J Immunol 180:4299-4307

Wang $\mathrm{H}$, Bloom $\mathrm{O}$, Zhang $\mathrm{M}$, Vishnubhakat J, Ombrellino $\mathrm{M}$ et al (1999) HMG-1 as a late mediator of endotoxin lethality in mice. Science 285:248-251

Wang Y, Kelly CG, Karttunen JT, Whittall T, Lehner P et al (2001) CD40 is a cellular receptor mediating mycobacterial heat shock protein 70 stimulation of CC-chemokines. Immunity 15:971-983

Wang R, Kovalchin JT, Muhlenkamp P, Chandawarkar RY (2006) Exogenous heat shock protein 70 binds macrophage lipid raft microdomain and stimulates phagocytosis, processing, and MHC-II presentation of antigens. Blood 107:1636-1642

Wolf P (1967) The nature and significance of platelet products in human plasma. Br J Haematol 13:269-288 
Yang H, Wang H, Czura CJ, Tracey KJ (2005) The cytokine activity of HMGB1. J Leukoc Biol 78:1-8

Zhang X, He M, Cheng L et al (2008) Elevated heat shock protein 60 levels are associated with higher risk of coronary heart disease in Chinese. Circulation 118:2687-2693

Zhang X, Xu Z, Zhou L, Chen Y, He M, Cheng L, Hu FB, Tanguay $\mathrm{RM}, \mathrm{Wu} \mathrm{T}$ (2010a) Plasma levels of Hsp70 and anti-Hsp70 antibody predict risk of acute coronary syndrome. Cell Stress Chaperones 15:675-686

Zhang Y, Liu R, Ni M, Gill P, Lee AS (2010b) Cell surface relocalization of the endoplasmic reticulum chaperone and unfolded protein response regulator GRP78/BiP. J Biol Chem 285:15065-15075

Zheng H, Nagaraja GM, Kaur P, Asea EE, Asea A (2010) Chaperokine function of recombinant $\mathrm{Hsp} 72$ produced in insect cells using a baculovirus expression system is retained. J Biol Chem 285:349-356
Zhu J, Quyyumi AA, Wu H, Csako G, Rott D, Zalles-Ganley A, Ogunmakinwa J, Halcox J, Se E (2003) Increased serum levels of heat shock protein 70 are associated with low risk of coronary artery disease. Arterioscler Thromb Vasc Biol 23:1055-1059

Ziegler TR, Ogden LG, Singleton KD, Luo M, Fernandez-Esstivariz C, Griffith D, Galloway J, Wischmeyer P (2005) Parenteral glutamine increases serum heat shock protein 70 in critically ill patients. Intensive Care Med 31:1079-1086

Zitvogel L, Regnault A, Lozier A, Wolfers J, Flament C, Tenza D, Ricciardi-Castagnoli P, Raposo G, Amigorena S (1998) Eradication of established murine tumors using a novel cell-free vaccine: dendritic cell-derived exosomes. Nat Med 4:594-600

Zwaal RF, Comfurius P, Bevers EM (2005) Surface exposure of phosphatidylserine in pathological cells. Cell Mol Life Sci 62:971-988 